\title{
Status Gizi dan Usia Saat Menarche Berkorelasi terhadap Kejadian Dismenore Siswi SMP
}

\author{
Ni Putu Sri Ratna Dewi ${ }^{1}$, Desak Made Citrawathi ${ }^{2}$, Ni Putu Wahyunita Savitri ${ }^{3}$ \\ 1,2,3 Program Studi Pendidikan Biologi, Jurusan Biologi dan Perikanan Kelautan, Universitas Pendidikan Ganesha, Indonesia
}

\section{Keywords:}

Nutritional status;

Menarche;

Dysmenorrhea.

ABSTRACT

Abstract: The purpose of this study was to determine: the relationship of nutritional status with the incidence of dysmenorrhea and the relationship between age of menarche and the incidence of dysmenorrhea in junior high school students. This type of research is a correlational study with 65 respondents who were determined by simple random sampling technique. Statistical tests using Product Moment correlation at a significance level of 5\%. Statistical analysis showed that the relationship between nutritional status and the incidence of dysmenorrhea obtained $p$ value $=0.008$ with a value of $r=0.324$, and for the results of the relationship between menarche age and dysmenorrhea events a value of $p=0.005$ with a value of $r=0.341$ and an $R$ value of 0.430 . From the results of the analysis it can be concluded that: 1) there is a significant relationship between nutritional status and the incidence of dysmenorrhea, 2) there is a significant relationship between the age of menarche and the incidence of dysmenorrhea with a low level of relationship. Nutritional status and age at menarche contribute $43 \%$ to the incidence of dysmenorrhea.
\end{abstract}

\begin{abstract}
Abstrak: Tujuan penelitian ini adalah untuk mengetahui: hubungan status gizi dengan kejadian dismenore dan hubungan usia menarche dengan kejadian dismenore pada siswi SMP. Jenis penelitian ini adalah penelitian korelasional dengan responden berjumlah 65 orang yang ditentukan dengan teknik simple random sampling. Uji statistik menggunakan korelasi Product Moment pada taraf signifikansi 5\%. Hasil analisis statistik menunjukan untuk hasil hubungan status gizi dengan kejadian dismenore, diperoleh nilai $p=0,008$ dengan nilai $r$ $=0,324$, dan untuk hasil hubungan usia menarche dengan kejadian dismenore nilai $p=0,005$ dengan nilai $r=0,341$ serta didapatkan nilai $R$ sebesar 0,430 . Dari hasil analisis tersebut dapat disimpulkan bahwa: 1) terdapat hubungan yang signifikan antara status gizi dengan kejadian dismenore, 2) terdapat hubungan yang signifikan antara usia menarche dengan kejadian dismenore dengan tingkat hubungan yang rendah. Status gizi dan usia saat menarche berkontribusi sebesar $43 \%$ terhadap kejadian dismenore.
\end{abstract}

Correspondance address:

E-mail: ratna.dewi@undiksha.ac.id (Ni Putu Sri Ratna Dewi) 


\section{Pendahuluan}

Kesehatan merupakan hal penting dalam hidup manusia karena dengan tubuh yang sehat semua aspek kehidupan manusia dapat berjalan dengan baik. Kesehatan sangat bergantung pada keseimbangan gizi dalam tubuh. Status gizi yang dimiliki seseorang tidak akan lepas dari jenis makanan yang dikonsumsi sehari-hari.

Pada prinsipnya, seseorang dikatakan sudah berperilaku makan sehat apabila menu yang dikonsumsinya sudah mengandung gizi seimbang. Gizi seimbang ini hanya dapat diperoleh dari beraneka ragam bahan makanan. Kesadaran untuk pola makan yang sehat tersebut sampai saat ini umumnya belum dimiliki oleh remaja. Terdapat kecenderungan untuk makan di luar rumah, yaitu di tempat bergengsi dengan pilihan menu tidak memenuhi asas gizi seimbang. Makanan cepat saji (fast food) adalah makanan yang tersedia dalam waktu cepat dan siap untuk disantap, seperti fried chicken, hamburger, atau pizza. Makanan cepat saji yang mudah diperoleh di pasaran memberikan variasi pangan sesuai selera dan daya beli (Sulistijani, 2002). Namun, fast food kurang menjamin kebutuhan gizi yang akan berdampak buruk pada kesehatan.

Jumlah dan jenis zat gizi yang terdapat pada makanan yang dikonsumsi dapat menentukan status gizi seseorang. Status gizi merupakan ukuran keberhasilan seseorang dalam pemenuhan nutrisi yang di indikasikan oleh berat badan dan tinggi badan (Depkes RI, 2017). Status gizi normal menentukan derajat kesehatan seseorang, termasuk kesehatan reproduksi. Zat gizi mempunyai nilai yang sangat penting bagi kesehatan reproduksi remaja seperti kalsium, besi, lemak, vitamin B12, dan vitamin C. Kalsium merupakan zat yang diperlukan dalam kontraksi otot, termasuk otot pada organ reproduksi. Bila otot kekurangan kalsium, maka otot tidak dapat mengendur setelah kontraksi, seperta halnya yang terjadi saat haid. Kondisi ini menyebabkan terjadinya kram otot dan menimbulkan rasa nyeri (Almatsier, 2009). Zat besi adalah komponen utama yang mempunyai peranan penting dalam pembentukan darah (hemopoiesis), yaitu untuk mensintesis hemoglobin. Hemoglobin berfungsi untuk mengikat oksigen yang akan diedarkan ke seluruh tubuh, jika kadar hemoglobin berkurang, maka oksigen yang diikat dan diedarkan ke seluruh tubuh hanya sedikit, termasuk ke organ reproduksi. Sedikitnya oksigen yang disalurkan oleh darah di organ reproduksi yang mengalami vasokontriksi akan menimbulkan rasa nyeri (Tjokronegoro, 2004).

Karyadi (dalam Dewantari, 2013) menyatakan bahwa menstruasi pada wanita tidak akan teratur jika tidak memiliki simpanan lemak kurang dari $20 \%$ dari total berat badan. Lemak dapat memicu produksi hormon terutama hormon estrogen. Peningkatan hormon estrogen menyebabkan peningkatan kontraktilitas uterus sehingga dapat menyebabkan dismenore (Iqlima dkk, 2015)

Kekurangan zat gizi mikro (vitamin dan mineral) mendorong kelebihan prostalglandin yang dapat memfasilitasi terjadinya nyeri haid pada bagian bawah perut yang muncul sebelum atau saat menstruasi atau sering disebut dengan dismenore. Konsumsi protein membantu merangsang produksi hormon estrogen selama menstruasi sehingga dapat mengurangi peradangan serta kram saat menstruasi (Dewantari, 2013). Vitamin B12 diperlukan dalam 
pembentukan sel darah merah, vitamin $\mathrm{C}$ berfungsi meningkatkan kesuburan, memperkuat imun tubuh dan membantu penyerapan zat besi yang diperlukan dalam pembetukan sel darah merah (Dewantari, 2013).

Saat menstruasi, tidak sedikit dari wanita yang mendapatkan menstruasi disertai keluhan sehingga mengakibatkan rasa ketidaknyamanan berupa dismenore. Dismenore merupakan nyeri perut bagian bawah yang terkadang rasa nyeri tersebut meluas hingga ke pinggang, punggung bagian bawah, dan paha (Badziad, 2008). Penyebab utama dismenore primer adalah adanya prostaglandin F2a (PGF2a) yang dihasilkan di endometrium. PGF2a merupakan hormon yang diperlukan untuk menstimulasi kontraksi uterus selama menstruasi (Varney, 2008). Semakin tinggi kadar prostaglandin maka semakin tinggi peluang terjadinya dismenore. Ernawati (2010) menyatakan bahwa dismenore terjadi akibat ketidakseimbangan hormon progesteron dalam darah sehingga paling sering mengakibatkan timbul rasa nyeri yang terjadi pada wanita. Kadar progesteron yang rendah menyebabkan terbentuknya prostalglandin yang banyak sehingga kontraktilitas otot uterus meningkat dan terjadi dismenore. Prostaglandin menyebabkan otot rahim berkontraksi sebagai reaksi inflamasi terhadap peluruhan dinding rahim. Kadar prostaglandin yang tinggi dapat menyebabkan nyeri perut dan kram yang parah.

Angka kejadian nyeri menstruasi di dunia sangat besar. Rata-rata lebih dari 50\% perempuan di setiap negara mengalami nyeri menstruasi. Di Amerika angka presentasenya sekitar $60 \%$ dan di Swedia sekitar 72\%. Sementara di Indonesia angkanya diperkirakan 55\% perempuan usia produktif yang tersiksa oleh nyeri selama menstruasi (Proverawati dan Misaroh, 2009). Angka kejadian (prevalensi) nyeri menstruasi berkisar $45-95 \%$ di kalangan wanita usia produktif. Walaupun pada umumnya dismenore tidak berbahaya, namun seringkali dirasa mengganggu bagi wanita yang mengalaminya (Proverawati dan Misaroh, 2009).

Salah satu faktor yang dapat menimbulkan dismenore adalah status gizi (Nurwana, dkk. 2017). Wanita yang obesitas atau overweight dapat menjadi faktor risiko dari dismenore karena saat kelebihan berat badan maka terdapat jaringan lemak yang berlebihan yang dapat mengakibatkan hiperplasi pembuluh darah atau terdesaknya pembuluh darah oleh jaringan lemak pada organ reproduksi wanita, sehingga darah yang seharusnya mengalir pada proses menstruasi terganggu dan mengakibatkan nyeri pada saat menstruasi (Nurwana, dkk. 2017). Tingginya akumulasi lemak, terutama pada daerah perut (intra-abdominal fat) memicu jaringan adiposa menghasilkan hormon dalam jumlah yang tidak normal. Seseorang dengan underweight ternyata juga dapat mengalami dismenore, hal ini disebabkan karena asupan zat gizi yang kurang seperti asupan zat besi.

Menstruasi pertama atau menarche yang dialami oleh wanita usia subur (WUS) merupakan tanda awal masuknya seorang perempuan dalam masa reproduksi. Usia paling lama mendapat menarche adalah 16 tahun (Nurwana, dkk. 2017). Usia mendapat menarche tidak pasti atau bervariasi, akan tetapi terdapat kecenderungan bahwa dari tahun ke tahun wanita remaja mendapat haid pertama pada usia yang lebih muda. Menarche dini merupakan menstruasi pertama yang dialami seorang wanita subur pada usia di bawah 12 tahun (Fuadah, 2016). 
Di Indonesia, khususnya provinsi Bali menurut Kementrian Kesehatan tahun 2017, prevalensi status gizi IMT/U untuk umur 12 s.d 18 tahun ialah 2,2\% kurus, 71,4\% normal, $19,7 \%$ gemuk dan $6,7 \%$ obesitas. Dari 34 provinsi yang ada di Indonesia, provinsi Bali mempunyai prevalensi tertinggi ketiga setelah Jawa Timur dan Gorontalo untuk angka obesitas. Dalam hal usia menarche yang dialami oleh remaja putri, Riset Kesehatan Dasar (2010) melaporkan bahwa Provinsi Bali memiliki prevalensi cukup tinggi yaitu 12,9\% untuk usia menarche 11 s.d 12 tahun serta 40,5\% untuk usia menarche 13 s.d. 14 tahun.

Berdasarkan penelitian awal yang dilakukan tanggal 7 Desember 2018 pada 20 siswi kelas VIII SMP Negeri 2 Sawan didapatkan hasil bahwa semua siswi sudah mengalami menstruasi, dimana 17 orang di antaranya memiliki keluhan berupa nyeri pada bagian perut serta pusing saat menstruasi dan 3 siswi lainnya tidak mengalami keluhan apapun saat menstruasi. Dari 17 siswi tersebut terdapat 4 siswi mengalami menarche dini, yaitu pada usia 11 tahun. Berdasarkan uraian di atas, perlu dilakukan pengkajian mengenai keterkaitan antara status gizi dan usia menarche dengan kejadian dismenore yang dialami remaja putri di kabupaten Buleleng khususnya di SMP Negeri 2 Sawan.

\section{Metode}

Jenis penelitian ini adalah penelitian korelasional. Penelitian ini dilaksanakan di SMP N 2 Sawan. Populasi terjangkau yang dilibatkan pada penelitian ini adalah siswi kelas VIII di SMP Negeri 2 Sawan yang terbagi dalam 11 kelas dengan jumlah 154 Orang. Kriteria inklusi yang digunakan dalam penelitian ini adalah: 1) siswi kelas VII SMP N 2 Sawan, 2) usia 12 s.d. 15 tahun, 3) sudah menstruasi, 4) bersedia menjadi subjek penelitian. Teknik pengambilan sampel yang digunakan adalah simple random sampling yang penentuan jumlah sampel ditentukan dengan menggunakan rumus Slovin yakni sebagai berikut.

$$
\begin{aligned}
& n=\frac{N}{1+N\left(e^{2}\right)} \\
& \mathrm{n}=\text { ukuran sampel } \\
& \mathrm{N}=\text { ukuran populasi } \\
& \mathrm{e}=0,1
\end{aligned}
$$

Dengan menggunakan rumus tersebut diperoleh jumlah sampel sebanyak 65 orang. Teknik pengambilan sampel dilakukan dengan tehnik undian sebagai berikut. (1) Menentukan jumlah sampel yang digunakan. (2) Menyiapkan potongan kertas berukuran kecil dengan jumlah 20 lembar, menulis angka 1 s.d 6 di setiap kertas yang berbeda kemudian gulung dan dimasukkan ke dalam wadah. (3) Siswa mengambil kertas dan yang mendapatkan kertas dengan angka 1 s.d 6 akan menjadi sampel di kelas tersebut. (4) Langkah nomer 3 diulang di kelas berikutnya. Pengambilan data berdasarkan kriteria inklusi yaitu (1) Usia 12-15 tahun, (2) Sudah menstruasi, (3) Bersedia menjadi subjek penelitian. Data diperoleh secara langsung dari siswi dengan menggunakan kuesioner dan pengukuran tinggi badan, berat badan untuk 
mendapatkan data status gizi. Data dianalisis menggunakan uji korelasi Product Moment, dan Uji Regresi dengan bantuan SPSS.

\section{Hasil dan Pembahasan}

Data hasil penelitian dianalisis secara deskriptif dan statistik. Usia responden terbanyak berada pada usi 14 tahun yaitu sebanyak 33 orang atau (50,775\%). Data mengenai distribusi frekuensi status gizi dan kejadian dismenore tersaji pada tabel 1.

Tabel 1 Distribusi Frekuensi Data Status Gizi dengan Kejadian Dismenore

\begin{tabular}{|c|c|c|c|c|}
\hline \multicolumn{2}{|c|}{ Kejadian Dismenore } & \multicolumn{3}{|c|}{ Status Gizi Responden } \\
\hline & & Kurus & Normal & Lebih \\
\hline \multirow[t]{2}{*}{ Dismenore } & Jumlah & 21 & 16 & 2 \\
\hline & $\%$ Total & $84 \%$ & $43,24 \%$ & $66,67 \%$ \\
\hline \multirow[t]{2}{*}{ Tidak Dismenore } & Jumlah & 4 & 21 & 1 \\
\hline & \%Total & $16 \%$ & $56,76 \%$ & $33,33 \%$ \\
\hline Total & & 25 & 37 & 3 \\
\hline
\end{tabular}

Tabel 1 menunjukan bahwa kejadian dismenore paling tinggi dialami oleh siswi dengan status gizi kurus dengan jumlah 21 orang (84\%) dari total jumlah 25 orang dengan status gizi kurus. Sedangkan dari 3 orang dengan status gizi obesitas terdapat 2 orang $(66,67 \%)$ yang mengalami dismenore serta yang paling rendah pada status gizi normal yaitu 16 orang $(43,24 \%)$.

Tabel 2 Distribusi Frekuensi Usia Menarche dengan Kejadian Dismenore

\begin{tabular}{llllllll}
\hline Kejadian Dismenore & \multicolumn{6}{l}{ Usia Menarche (Tahun) } & \multirow{2}{*}{ Total } \\
\cline { 3 - 7 } & & 10 & 11 & 12 & 13 & 14 & \\
\hline \multirow{2}{*}{ Dismenore } & Jumlah & 8 & 13 & 10 & 8 & 0 & 39 \\
\cline { 2 - 7 } & \% Total & $12,31 \%$ & $20 \%$ & $15,38 \%$ & $12,31 \%$ & $0 \%$ & $60 \%$ \\
\hline \multirow{2}{*}{$\begin{array}{l}\text { Tidak } \\
\text { Dismenore }\end{array}$} & Jumlah & 2 & 4 & 8 & 10 & 2 & 26 \\
\cline { 2 - 7 } Total & \% Total & $3,08 \%$ & $6,15 \%$ & $12,31 \%$ & $15,38 \%$ & $3,08 \%$ & $40 \%$ \\
\cline { 2 - 7 } & Jumlah & 10 & 17 & 18 & 18 & 2 & 65 \\
\hline & \% Total & $15,39 \%$ & $26,15 \%$ & $27,69 \%$ & $27,69 \%$ & $3,08 \%$ & $100 \%$ \\
\hline
\end{tabular}


Dilihat dari tabel 2, kejadian dismenore paling tinggi terjadi pada usia menarche dini (<12 tahun) yaitu 21 orang (32,31\%) dibandingkan usia menarche ideal (12-15 tahun), yaitu 18 orang $(27,69 \%)$.

Tabel 3 Keluhan Lain saat terjadi Dismenore

\begin{tabular}{llll}
\hline No & Keluhan Lain saat Dismenore & Jumlah & Persentase \\
\hline 1 & Rasa sakit di pinggang hingga paha & 8 & $20,51 \%$ \\
\hline 2 & Mual dan muntah & 3 & $7,69 \%$ \\
\hline 3 & Sakit kepala & 11 & $28,20 \%$ \\
\hline 4 & Perut kembung & 4 & $10,26 \%$ \\
\hline
\end{tabular}

Dilihat dari tabel 3, keluhan lain paling tinggi yang menyertai saat terjadinya dismenore adalah sakit kepala yang berjumlah 11 orang $(28,20 \%)$. Frekuensi paling rendah yaitu keluhan mual muntah berjumlah 3 orang (7,69\%).

Tabel 4 Hasil Uji Korelasi antara Status Gizi dan Usia Menarche dengan Kejadian Dismenore

\begin{tabular}{llll}
\hline No & Variabel & Nilai $\mathbf{r}$ & Nilai $\mathbf{p}$ \\
\hline $\mathbf{1}$ & Status Gizi dengan Kejadian Dismenore & 0,324 & 0,008 \\
\hline $\mathbf{2}$ & Usia Menarche dengan Kejadian Dismenore & 0,341 & 0,005 \\
\hline
\end{tabular}

Tabel 4 menunjukan hasil uji statistik terdapat hubungan antara Indeks Massa Tubuh dengan kejadian dismenore, yaitu memiliki nilai $p=0,008(p<0,05)$ dan nilai $r$ yang di dapat yakni 0,324 yang menunjukkan adanya tingkat korelasi yang rendah. Begitu pula dengan hasil statistik yang menunjukan korelasi antara usia menarche dengan kejadian dismenore, yaitu memiliki nilai $p=0,005(p<0,05)$ dan nilai $r$ yang didapat yakni 0,341 yang menunjukkan adanya tingkat korelasi yang rendah.

Tabel 5 Hasil Uji Kontribusi antara Status Gizi dan Usia Menarche dengan kejadian Dismenore

\begin{tabular}{llll}
\hline Variabel & Nilai R & Nilai p & Keterangan \\
\hline $\begin{array}{l}\text { Status Gizi dan Usia Menarche } \\
\text { dengan kejadian Dismenore }\end{array}$ & 0,430 & 0,002 & Berkontribusi 43\% \\
\hline
\end{tabular}

Berdasarkan tabel 5, hasil analisa menunjukan bahwa status gizi dan usia menarche berkontribusi sebesar $43 \%$ terhadap kejadian dismenore 


\section{Hubungan Antara Satus Gizi dengan Kejadian Dismenore}

Dari hasil analisis pada tabel tabel 1, mengenai distribusi frekuensi tingkat status gizi berdasarkan Indeks Massa Tubuh ditunjukan bahwa dari 65 jumlah responden, sebanyak 37 orang $(56,92 \%)$ memiliki status gizi normal, sedangkan 3 orang $(4,6 \%)$ memiliki status gizi lebih, dan 25 orang $(38,46 \%)$ memiliki status gizi kurus.

Menurut Marmi (2013), ada berbagai faktor yang mempengaruhi status gizi pada remaja, yaitu kebiasaan makan yang buruk dan pemahaman mengenai gizi yang keliru oleh remaja dimana tubuh yang langsing menjadi idaman bagi remaja putri sehingga mereka menerapkan pengaturan pembatasan makanan yang keliru. Waryana (2010) mengatakan bahwa, status gizi merupakan hal yang penting dari kesehatan manusia. Status gizi manusia dapat memengaruhi fungsi organ tubuh salah satunya adalah fungsi reproduksi. Remaja wanita perlu mempertahankan status gizi yang baik dengan cara mengonsumsi makanan seimbang. Asupan gizi yang baik akan mempengaruhi pembentukan hormon-hormon yang terlibat dalam menstruasi yaitu hormon FSH (FollicleStimulating Hormone), LH (Luteinizing Hormone), estrogen dan juga progesteron. Hormon $\mathrm{FSH}, \mathrm{LH}$ dan estrogen bersama-sama akan terlibat dalam siklus menstruasi, sedangkan hormon progesteron mempengaruhi uterus, yaitu dapat mengurangi kontraksi selama siklus haid (Trimayasari dan Kuswandi, 2013). Secara berkala, wanita yang normal akan mengalami menstruasi yang teratur. Proses ini berlangsung secara rutin setiap bulan. Tetapi ada pula perempuan yang memiliki keluhan lebih mendalam karena proses menstruasinya sudah dirasakan bermasalah baik siklus, jumlah darah, atau nyerinya (Kumalasari dan Andhyantoro, 2012). Keluhan saat menstruasi berupa rasa nyeri yang menyebabkan rasa ketidaknyamanan sering disebut dengan dismenore. Pada tabel 1 ditunjukan bahwa dari 65 orang responden, 39 orang (60\%) mengalami kejadian dismenore dan 26 orang (40\%) tidak mengalami dismenore.

Berdasarkan tabel 1 diketahui gambaran angka kejadian dismenore pada responden dengan status gizi kurus, normal, dan obesitas yang diukur melalui Indeks Masa Tubuh. Diketahui bahwa kejadian dismenore lebih banyak dialami oleh responden dengan status gizi kurus, yakni 21 orang (84\%) total jumlah respon, yaitu 25 orang. Tingginya angka kejadian dismenore pada responden dengan status gizi kurus dapat disebabkan beberapa faktor seperti produksi homon reproduksi yang tidak normal dan kebutuhan salah satu zat gizi dalam tubuh sangat kurang. Pada remaja putri dengan status gizi kurang terjadi penurunan hormon gonadotropin untuk mensekresi luteinizing hormone (LH) dan follicle stimulating hormone (FSH). Pada keadaan tersebut maka estrogen akan turun sehingga berdampak pada menstruasi. Ketidakseimbangan produksi estrogen akan menyebabkan terbentuknya prostaglandin. Ketika prostaglandin bertambah banyak maka menyebabkan vaso spasme pada arteriol uterin yang membuat iskemia dan kram pada perut bagian bawah sehingga terjadi rasa nyeri (Puspita dan Tingubun, 2017).

Hasil uji korelasi Product Moment didapatkan nilai $p=0,008,(p<0,05)$ maka terdapat hubungan antara status gizi dengan kejadian dismenore. Nilai $r$ yang di dapat yakni 0,324 yang berarti menunjukkan tingkat korelasi yang lemah antar variabel. Lemahnya hubungan status gizi dengan kejadian dismenore dapat disebabkan karena proses pengambilan data yang hanya terbatas pada Indeks Masa Tubuh, selain itu terdapat faktor lain seperti kurangnya kebiasaan olahraga, adanya riwayat keluarga dengan dismenore, serta belum pernah melahirkan.

Kejadian dismenore akan meningkat pada wanita yang kurang melakukan olahraga sehingga ketika wanita mengalami dismenore, oksigen tidak dapat disalurkan ke pembuluh pembuluh darah organ reproduksi yang saat itu terjadi vasokontriksi. Bila wanita teratur melakukan olahraga, maka wanita tersebut dapat menyediakan oksigen hampir dua kali lipat per menit sehingga oksigen tersampaikan ke pembuluh darah yang mengalami vasokontriksi. Hal itu akan menyebabkan terjadinya penurunan kejadian dismenore dengan teratur berolahraga (Ernawati, 2010). Riwayat keluarga juga menjadi faktor tejadinya dismenore karena menurut Ehrenthal, dkk. (2006), mengungkapkan bahwa riwayat keluarga (ibu atau saudara perempuan kandung) yang mengalami dismenore menyebabkan seorang wanita untuk menderita dismenore parah, hal ini berhubungan karena kondisi anatomis dan fisologis dari seseorang pada umumnya hampir sama dengan orang tua dan saudar-saudaranya. Selain itu, belum pernah melahirkan menjadi faktor penyebab lain terjadi 
dismenore karena dismenore timbul jika saluran canalis servix terlalu sempit, akibatnya darah yang menggumpal sulit keluar. Dismenore primer ini akan hilang jika wanita tersebut pernah melahirkan, karena saluran servixnya telah melebar Santoso (dalam Novia dan Puspitasari, 2008).

Faktor lain penyebab dismenore pada seseorang dapat disebabkan karena asupan zat gizi yang kurang seperti asupan zat besi. Zat besi adalah komponen utama yang mempunyai peranan penting dalam pembentukan darah (hemopoiesis), yaitu mensintesis hemoglobin. Hemoglobin berfungsi untuk mengikat oksigen yang akan diedarkan ke seluruh tubuh, jika kadar hemoglobin berkurang, maka oksigen yang diikat dan diedarkan ke seluruh tubuh hanya sedikit, akibatnya oksigen tidak dapat tersalurkan ke pembuluh darah di organ reproduksi yang mengalami vasokontriksi sehingga akan menimbulkan rasa nyeri (Tjokonegoro, 2004). Selain itu, wanita yang mengalami dismenore cenderung kekurangan zat gizi seng sehingga memiliki kadar prostaglandin tinggi. Seng memiliki kandungan antioksidan dan anti inflamasi yang berguna menghambat metabolisme prostalglandin.

Seseorang dengan status gizi overweight terjadi karena adanya jaringan lemak yang berlebihan yang dapat mengakibatkan hiperplasi pembuluh darah atau terdesaknya pembuluh darah oleh jaringan lemak pada organ reproduksi wanita, sehingga darah yang seharusnya mengalir pada proses menstruasi terganggu dan mengakibatkan nyeri pada saat menstruasi (Nurwana, dkk. 2017). Faktor lain yang mempengaruhi wanita obesitas mengalami dismenore adalah asam lemak yang berlebihan di dalam tubuh yang dapat mengganggu metabolisme progesteron pada fase luteal dari siklus menstruasi akibatnya terjadi peningkatan kadar prostaglandin yang akan menyebabkan rasa nyeri pada saat menstruasi.

Hasil penelitian ini sejalan dengan penelitian yang dilakukan oleh: (a) Ramadhayanti dan Rohmin (2016) yang menyebutkan bahwa ada hubungan antara status gizi dengan kejadian dismenore primer dengan nilai $\mathrm{p}=0,046$. (b) Achintya (2017) melaporkan bahwa terdapat hubungan signifikan antara Indeks Massa Tubuh (IMT) dengan kejadian dismenore primer dengan nilai $p=0,036$. (c) Sugiharti (2018), yang menyatakan bahwa ada hubungan antara status gizi dengan kejadian nyeri haid primer dengan angka kejadian dismenore paling tinggi terjadi pada responden dengan status gizi overwight, yakni 15 reponden dan paling sedikit terjadi pada responden dengan status gizi normal.

\section{Hubungan Usia Menarche dengan Kejadian Dismenore}

Dari hasil analisis pada tabel 2, ditunjukkan mengenai gambaran kejadian dismenore pada usia menarche responden. Angka kejadian dismenore paling tinggi terjadi pada usia menarche 11 tahun, yakni sebanyak 13 reponden dan terendah pada usia menarche 14 tahun karena tidak ada responden yang mengalami dismenore pada usia ini. Untuk mengetahui hubungan antara usia menarche dengan kejadian dismenore, maka dilakukan uji korelasi Product Moment dengan bantuan SPSS yang dapat dilihat pada tabel 4 . Hasil analisis korelasi tersebut mendapatkan nilai $p=0,005$, karena $p<0,05$ maka terdapat hubungan antara usia menarche dengan kejadian dismenore. Nilai $r$ yang di dapat, yakni 0,341 yang berarti menunjukkan tingkat korelasi lemah antarvariabel.

Menarche terjadi akibat peningkatan FSH dan LH yang merangsang sel target ovarium. FSH dan LH berkombinasi dengan reseptor FSH dan LH yang selanjutnya akan meningkatkan laju kecepatan sekresi, pertumbuhan dan poliferasi sel. Estrogen dan progesterone akan menstimulus uterus dan kelenjar payudara agar kompeten memungkinkan terjadinya ovulasi. Ovulasi yang tidak dibuahi akan memicu terjadinya menstruasi (Guyton, 2007).

Subjek dengan usia menarche dini ( $<12$ tahun) memiliki frekuensi yang cukup tinggi, yaitu 27 orang (41,54\%). Hal ini disebabkan karena membaiknya standar kehidupan terutama faktor asupan makanan dan genetik akan mengakibatkan menstruasi pertama terjadi lebih awal atau lebih cepat dari kebiasaan yang berlaku secara umum di tengah-tengah masyarakat. Faktor rendahnya asupan serat dan tingginya asupan lemak maupun kalsium berdampak pada usia menarche dini (Susanti, 2012).

Tingginya jumlah responden dengan usia dini (<12 tahun) yang mengalami dismenore dapat disebabkan karena ketidaksiapan organ-organ reproduksi yang belum berkembang secara maksimal dan adanya penyempitan pada leher rahim sehingga menimbulkan rasa nyeri saat menstruasi. 
Rosenthal (dalam Fuadah, 2016), kondisi menarche dini karena mendapat produksi hormon esterogen lebih banyak dibanding wanita lain pada umumnya.

Hal ini sejalan dengan hasil penelitian yang dilakukan oleh: (1) Rosanti (2017) pada siswi kelas VIII SMP Negeri 1 Ungaran dengan hasil ada hubungan antara usia menarche dengan dismenore $(p=0,029)$. (2) Sari (2017) melaporkan bahwa terdapat hubungan yang bermakna antara umur menarche dengan kejadian dismenorea dengan nilai $p=0,000$. Hasil penelitian menunjukkan umur menarche $<12$ tahun 48 orang $(66,7 \%)$ mengalami kejadian dismenorea, sedangkan 24 orang $(33,3 \%)$ tidak mengalami kejadian dismenorea. Pada kelompok umur menarche $\geq 12$ tahun 18 orang $(31,0 \%)$ mengalami dismenore, sedangkan 40 orang $(69,9 \%)$ tidak mengalami kejadian dismenorea. (3) Soesiowati dan Annisa (2016) yang menyatakan bahwa terdapat hubungan antara usia menarche dengan kejadian dismenore primer. Hasil penelitiannya menunjukkan bahwa angka kejadian dismenore lebih tinggi dialami oleh responden dengan usia menarche dini, yakni 42 responden $(62,7 \%)$ dengan jumlah responden yang tidak mengalami dismenore, yaitu 25 responden (37,3\%). (4) Ramadhayanti dan Rohmin (2016) yang melaporkan bahwa terdapat hubungan yang bermakna antara usia menarche dengan dismenorhea primer. Hasil penelitian menunjukkan dari total 75 responden, yang mengalami kejadian dismenore primer dengan usia menarche tidak normal sebanyak 41 responden, sedangkan kejadian dismenore primer pada usia menarche normal sebanyak 20 orang.

Keluhan lain yang yang menyertai saat terjadi dismenore seperti sakit kepala yang disebabkan karena hormon estrogen yang turun selama menstruasi sehingga dapat memicu sakit kepala. Hormon estrogen juga berfungsi mengaktifkan bagian otak yang mengatur rasa nyeri. Semakin rendah estrogen, semakin sedikit pula sumber daya otak untuk meredakan nyeri atau mematikan rasa sakit. Keluhan lain seperti mual atau muntah serta perut kembung terjadi karena produksi prostaglandin (senyawa yang terdapat dalam kelenjar kelamin) saat siklus haid berlangsung. Hal ini kemudian membuat dinding rahim berkontraksi dan menyebabkan mual dan kram perut.

\section{Simpulan}

Berdasarkan hasil dan pembahasan yang telah diuraikan dapat disimpulkan sebagai berikut.

1. Ada hubungan antara status gizi dengan kejadian dismenore pada siswi SMP yang menunjukan tingkat korelasi rendah dengan nilai $p=0,008(p<0,05)$ dan $r=0,324$.

2. Ada hubungan antara usia menarche dengan kejadian dismenore pada siswi SMP yang menunjukkan tingkat korelasi rendah dengan nilai $p=0,005(p<0,05)$ dan $r=0,341$.

\section{Daftar Pustaka}

Achintya, A. A. S. A. 2017. Hubungan Antara Indeks Massa Tubuh (IMT) Dengan Kejadian Dismenore Primer Pada Mahasiswi Semester 7 Fakultas Kedokteran Universitas Hang Tuah Surabaya. Skripsi. Fakultas Kedokteran Universitas Hang Tuah. Surabaya.

Almatsier. 2009. Prinsip Dasar Ilmu Gizi. PT Gramedia Pustaka Utama. Jakarta.

Baziad, A. 2008. Kontrasepsi Hormonal. Jakarta: PT. Bina Pustaka Sarwono Prawirohardjo.

Dewantari,N.M. 2013. Peranan Gizi Dalam Kesehatan Reproduksi. Jurnal Skala Husada. 10(2): 219224.

Ehrenthal, D., Hoffman, M., Hillard P.A. 2006. Menstrual disorder. USA : ACP Press.

Ernawati. T. Hartiti, I. Hadi. 2010.Terapi relaksasi terhadap nyeri dismenore pada mahasiswi Universitas muhammadiyah semarang. Prosiding Seminar Nasional Unimus. Universitas Muhamadiyah Semarang: 106-113.

Fuadah, F. 2016. Hubungan Antara Status Gizi Dengan Usia Menarche Dini pada Remaja Putri di SMP Umi Kulsum Banjaran Kab. Bandung Provinsi Jawa Barat Tahun 2016. Jurnal IImu kesehatan. 10(2): 707-714. 
Iqlima, A.A., Wicaksono, A., Effiana. 2015. Hubungan Antara Tebal Lipatan Lemak Bawah Kulit Dan Dismenore Primer Pada Siswi SMA Swasta Muhammadiyah 1 Kota Pontianak Kalimantan Barat. Jurnal Mahasiswa PSPD FK Universitas Tanjungpura. 3(1): 1-14.

Kementrian Kesehatan Republik Indonesia. 2017. Buku Saku Pemantauan Status gizi tahun 2017. Jakarta. Kemenkes RI.

Marmi. 2013. Gizi dalam Kesehatan Reproduksi. Yogyakarta: Pustaka Belajar.

Nurwana, Sabilu., Y., A.F Fachlevy. 2017. Analisis Faktor Yang Berhubungan Dengan Kejadian Disminorea Pada Remaja Putri Di SMA Negeri 8 Kendari Tahun 2016. Jurnal Ilmiah Mahasiswa Kesehatan Masyarakat 2(6):1-14.

Puspita, D., Tingubun, S. 2017. Hubungan antara Status Gizi dan Siklus Menstruasi pada Remaja Putri. Jurnal IImu Kebidanan. 3(2): 99-130.

Ramadhayanti, E., Rohmin, A. 2016. Hubungan Status Gizi Dan Usia Menarche Dengan Dismenorhea Primer Pada Remaja Putri Kelas Xi Sma Negeri 15 Palembang. Jurnal Kesehatan. VII(2):255-259.

Riset Kesehatan Dasar. 2010. Badan Penelitian dan Pengembangan Kesehatan. Jakarta: Departemen Kesehatan, Republik Indonesia.

Rosanti, A. 2017. Faktor-faktor yang mempengaruhi kejadian disminore pada siswi kelas VIII SMP Negeri 1 Ungaran Kabupaten Semarang tahun 2017. Skripsi. Universitas Ngudi Waluyo Ungaran.

Sari. A.P. 2017. Faktor - Faktor yang Berhubungan dengan Kejadian Dismenorea pada Siswi SMK Swasta Istiqlal Deli Tua Kabupaten Deli Serdang. Skripsi. Fakultas Kesehatan Masyarakat Universitas Sumatera Utara. Medan.

Soesilowati, R., Annisa., Y. 2016. Pengaruh Usia Menarche Terhadap Terjadinya Disminore Primer Pada Siswi Mts Maarif Nu Al Hidayah Banyumas. Jurnal IImiah IImu-IImu Kesehatan 14(3):8-14.

Sugiharti. R. K. 2018. Hubungan Antara Status Gizi Dengan Kejadian Dismenore. Jurnal Kesehatan AlIrsyad. XI (2): 19-25.

Sugiyono. 2011. Metode Penelitian Kuantitatif, Kualitatif dan R\&D. Bandung: Afabeta.

Sulistijani, D.A. 2002. Sehat Dengan Menu Berserat. Jakarta: Trubus Agriwidya.

Susanti, A.V., Sunarto. 2012. Faktor Resiko Kejadian Menarche Dini Pada remaja Di SMP N 30 Semarang. Jurnal Of Nutrition College. 1(1): 115-126.

Tjokronegoro, E. 2011. Pendidikan Jasmani dan Olahraga. Jakarta: PT. Rajagrafindo Persada.

Trimayasari, D., Kuswandi, K. 2013. Hubungan Usia Menarche Dan Status Gizi Siswi SMP Kelas 2 Dengan Kejadian Dismenore. Jurnal Obstretika Scientia 2(2): 192-211.

Varney.2008. Buku Ajar Asuhan Kebidanan. Jakarta: EGC.

Waryana. 2010. Gizi Reproduksi. Yogyakarta: Pustaka Rahima. 